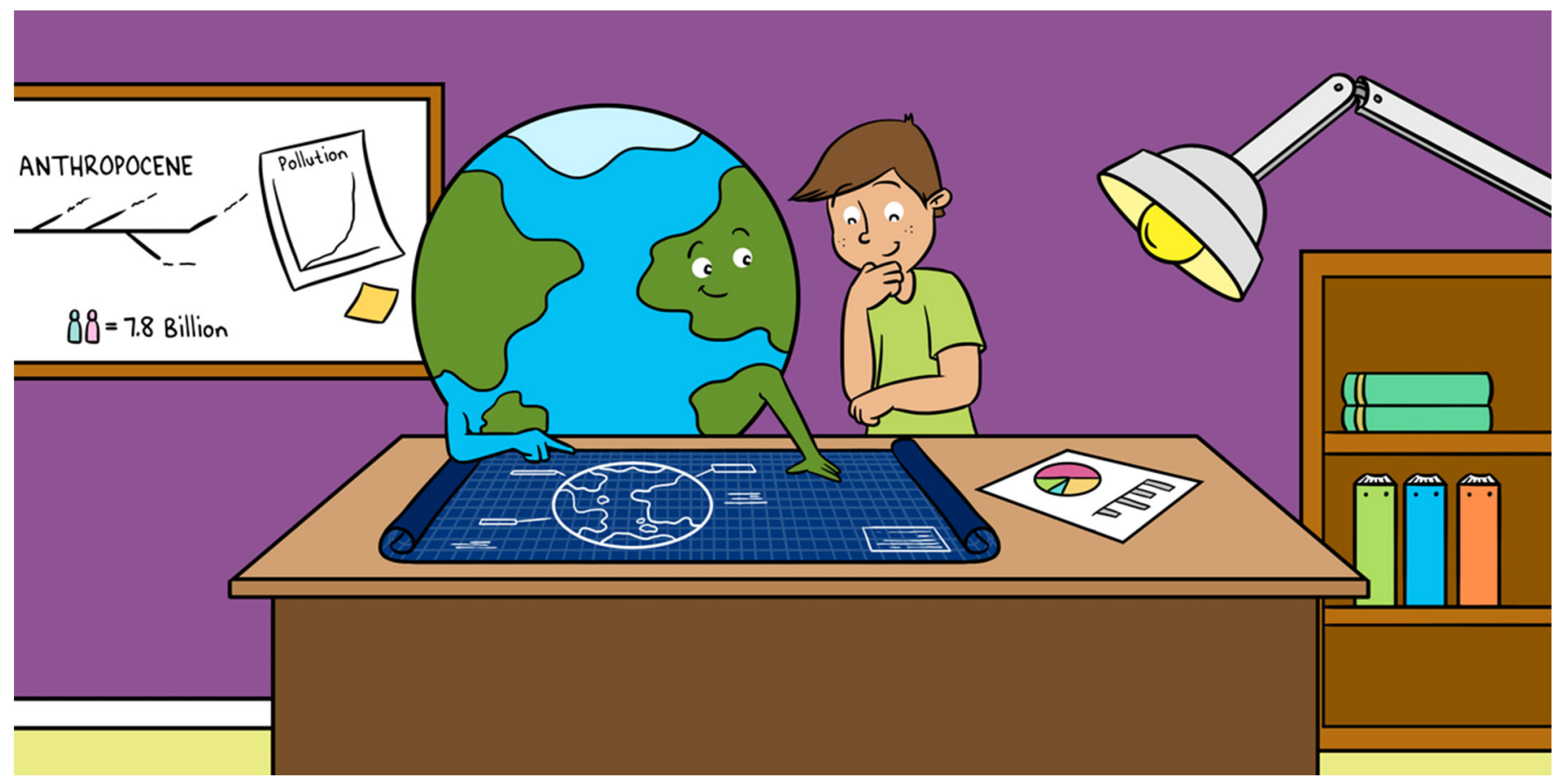

\title{
LEARNING HOW TO MANAGE A PLANET
}

\section{David Christian *}

Big History Institute, Macquarie University, Sydney, NSW, Australia

\section{YOUNG REVIEWERS:}

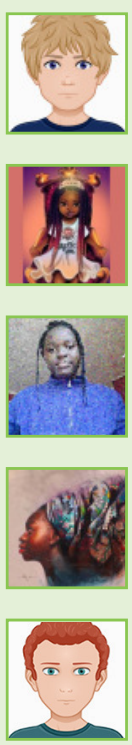

GABRIEL

AGE: 16

PRICE

AGE: 12

PRINCESS

AGE: 14

PROVIDENCE

AGE: 8

THEODORE

AGE: 13
We live at a turning point in the history of planet earth, and we need to understand what is going on. Suddenly, we humans are becoming so powerful that what we do in the next few decades will shape the future of our planet. Unfortunately, most modern education is too narrow to help us see how our relationship with the planet is changing. To see that, and to understand the huge challenges we face, we need to understand the history of planet earth and how human history fits into the planet's history. This is the story that is told in what are called big history courses. The task for the next generation is nothing less than to learn to manage an entire planet, and to manage it well for the sake of future generations. We have the resources we need, if only we can see the challenge clearly enough and agree on what needs to be done.

\section{A TURNING POINT IN HUMAN HISTORY}

Today's world is utterly different from the world I grew up in. When I was at school, in the middle of the twentieth century, I had no idea how powerful we humans were becoming. I did know that some scary 
Figure 1

For most of human history, population was very slow. What this graphs shows is how population growth has accelerated in just the last few centuries. At the end of the last ice age, 10,000 years ago, there were about 5 million humans on earth. Even 2,000 years ago, there were only about 250 million humans. Then, in the last 1,000 years population growth accelerated. By 1700 there were 600 million and sometime in the nineteenth century, we crossed the billion mark. Source: Our World in Data website: https://ourworldindata .org/worldpopulation-growth.

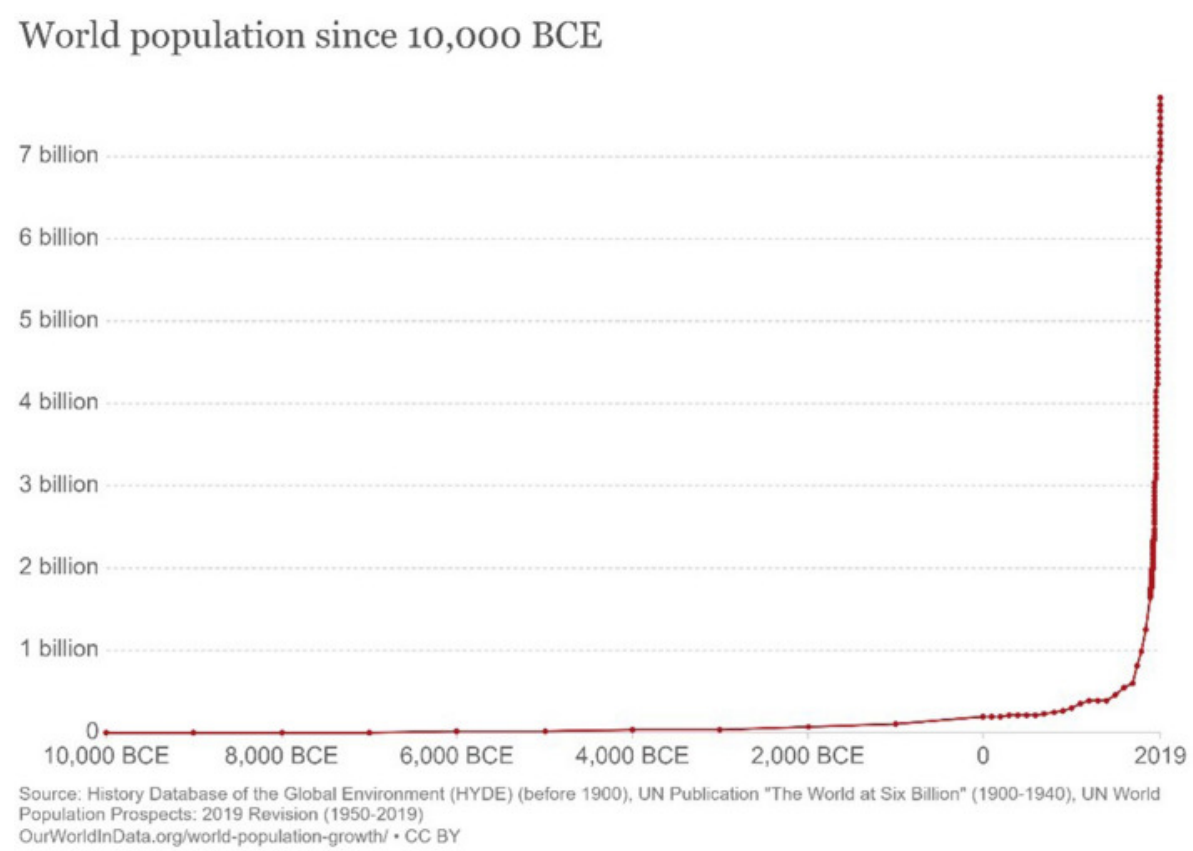

Figure 1

things were happening because I was scared of nuclear war. I was at school in 1962 when the world came close to an all-out nuclear war during the Cuban Missile Crisis. For a few days, I thought that I and my friends and much of the world was about to be blown up. When asked how close we had come to all-out nuclear war, the American President, John F. Kennedy (one of the two people who made the critical decisions) said it was between 1 in 3 and 1 in 2 . Very close! [1].

Today, the nuclear weapons are still there. But since the time I was at school, we have begun to change the world in many other ways. To see this clearly, we need to measure these changes. It is worth looking at these measurements closely.

When I was a child in 1950, there were 2.5 billion people in the world. Today, there are about 7.8 billion (Figure 1). That is a huge change! There are five billion more people on planet earth than when I was at school! Such a population increase has never happened before. Remarkably, our ability to produce the food, housing, and other things that all these people need has increased even faster. So today, more and more people are living longer, healthier, and wealthier lives than ever before. The proportion of those living on $<\$ 1$ a day has fallen fast, from about $50 \%$ when I was at school, to $<10 \%$ today (Figure 2 ). This is because living standards have risen quickly in countries, such as China and India.

But of course, nothing is free. All these changes depended on huge increases in our use of energy. Today, humans are using more than 
Figure 2

For most of human history, most people had just enough to survive. More than 50\% of babies died before the age of 5 and most people suffered hunger regularly. Only a tiny minority of people lived more prosperous lives. What this graph shows is that we have all got much better off in the last 200 years. In that time, the number living in extreme poverty has fallen from over $85 \%$ to $<10 \%$. Note: "Extreme poverty" $=<\$ 2 /$ day Source: Rosling and Rosling [2], kindle ed., p. 51, and Roser [3] Our World in Data website: https://ourworldindata .org/.

\section{FOSSIL FUELS}

Sources of energy from plants and organisms that were buried several hundred million years ago and fossilized; they include coal, oil, and natural gas.

\section{ANTHROPOCENE} ERA

The modern era of human history, since the middle of the twentieth century; the era in which humans dominate change on planet earth.

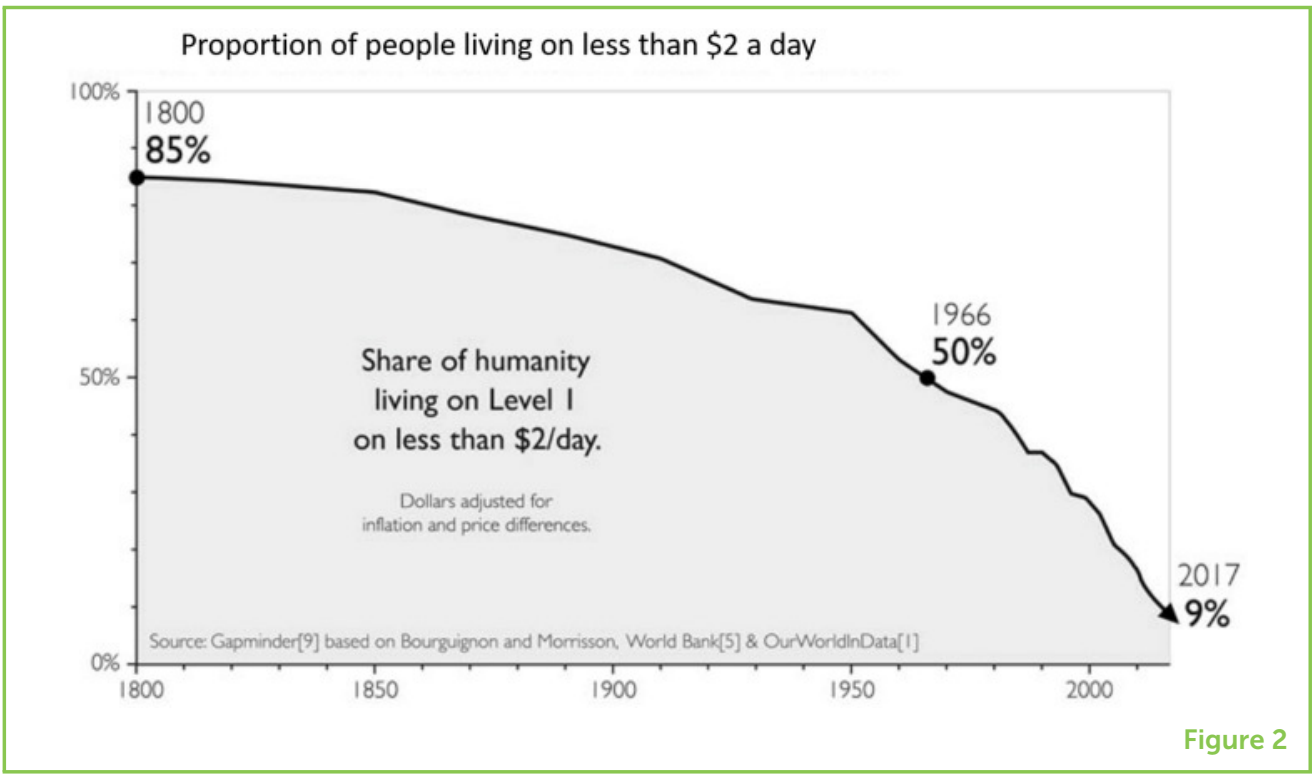

five times as much energy as they used in 1950 (Figure 3). Most of that energy comes from fossil fuels. As you surely know, burning fossil fuels puts a lot of carbon dioxide into the atmosphere, which tends to make the world hotter. Climates in the future will become less predictable. Since 1950, the amount of carbon dioxide we humans are pumping into the atmosphere has increased by almost seven times (Figure 4).

We are already beginning to see the effects. As I wrote the first draft of this article in January 2020 in Sydney, the air around me was smoky from the worst bush fires Australia has ever experienced. Several lives were lost, hundreds of homes, farms, and business burned down, and millions of wild animals died. As humans have used more and more resources, other species have suffered and their numbers have fallen sharply. The Covid-19 pandemic is another sign of the dangers of modern technology, because modern air travel can carry viruses around the world in just a few hours.

\section{WHAT IS GOING ON?}

These numbers are telling us something very important about the world we live in today. Human history is at a turning point. Things are changing faster and faster. That is why some scholars say that a new historical era has begun. They call it the Anthropocene, the era of earth's history that is dominated by a single species: humans.

It is not easy to see all this if you study the world as we normally do at school. If you study a bit of the history of your home country, or some literature, or perhaps a bit of physics or maths, you would not be able to see these changes. To see them you need a sort of wide-angle lens. You need to study how things have changed over thousands 
Figure 3

For most of human history, most energy came from agriculture (food), from humans working very hard, from domesticated animals, such as oxen and horses, and from the burning of wood. Then from the eighteenth century, we learned how to use an entirely new source of cheap energy: fossil fuels. Suddenly, machines could do the work we had once done. What this graph shows is that in just 200 years, the amount of energy we can use has multiplied by more than 30 times. Source: Our World in Data website: https://ourworldindata .org/energy.

\section{BIG HISTORY}

Courses that teach the whole history of the universe. Big history courses show how human history is linked to, and is now shaping, the history of planet earth.

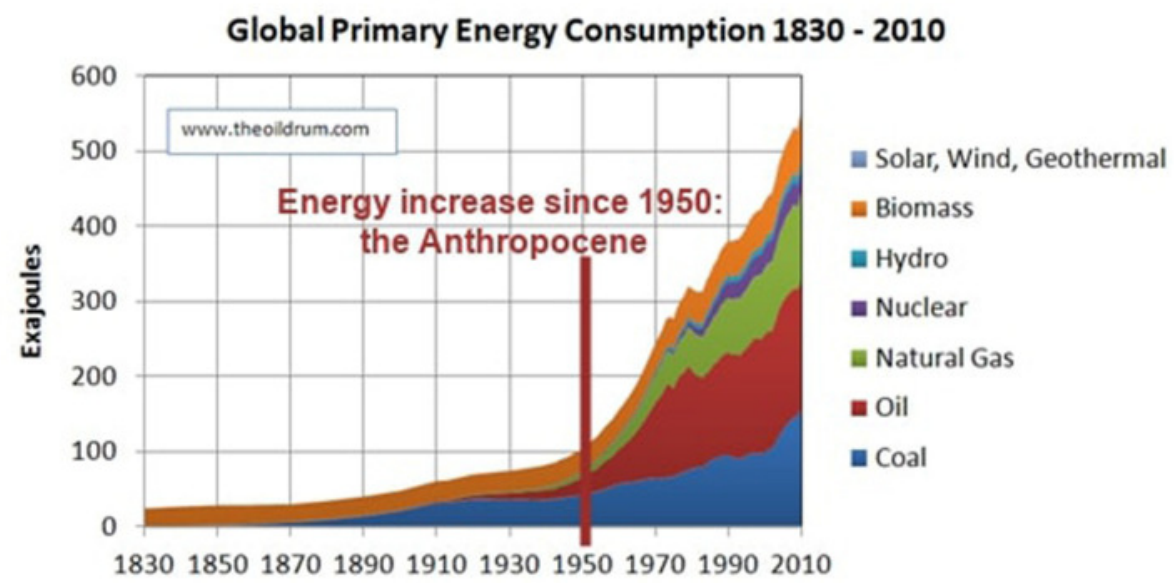

Figure 3

or even millions of years, to see how quickly we are changing the planet. Additionally, you need some understanding of how our earth was formed 4.5 billion years ago, how the planet's climates have evolved, and how new types of organisms appeared on earth. How many schools teach the history of planet earth, our home?

This is the story that big history courses teach [4-6]. Big history courses show that today we live at a tipping point in our planet's history. For the first time in the 4 billion years since life first appeared on earth, a single species (us-you and me!) is using so much energy and so many resources that we are beginning to change the entire planet. We are transforming the atmosphere, the land, the oceans, and the other species with which we share planet earth. We became a planet-changing species quite recently-during my lifetime. And what we do in the next 50 years, during your lifetimes, will shape the future of the earth for millions of years. The task for your generation is to learn how to become good planet-managers! That is a daunting task, but it is also exciting.

\section{HOW DID WE GET HERE AND WHERE ARE WE GOING?}

How did we get here? What happened? The best answer I know is that we humans developed more and more powerful ways of changing our world. The key was human language. Humans can talk to each other with such precision that we can share ideas in ways that no other species can match. Chimps and dolphins are extremely smart animals, but they cannot share much information. Our technologies were created by humans sharing new ideas over thousands of years so that, from generation to generation, we accumulated more and more knowledge about how to control our surroundings. As populations grew, humans learnt more and more powerful ways of managing the land, the rivers, the plants, and the animals around 
Figure 4

For most of human history, human activities did not have much impact on the global environment. But burning fossil fuels releases greenhouse gases, such as carbon dioxide. What this graph shows is that in just the last 200 years human emissions of carbon dioxide have increased by more than 1,000 times. Source: Our World in Data website: https://ourworldindata .org/co2-andother-greenhousegas-emissions\#co2in-the-atmosphere.

\section{COLLECTIVE LEARNING}

The ability of humans to share ideas with a speed and precision unmatched by any other species; collective learning means that ideas accumulate from generation to generation, giving us more and more power over our environment.
Annual total $\mathrm{CO}_{2}$ emissions, by world region

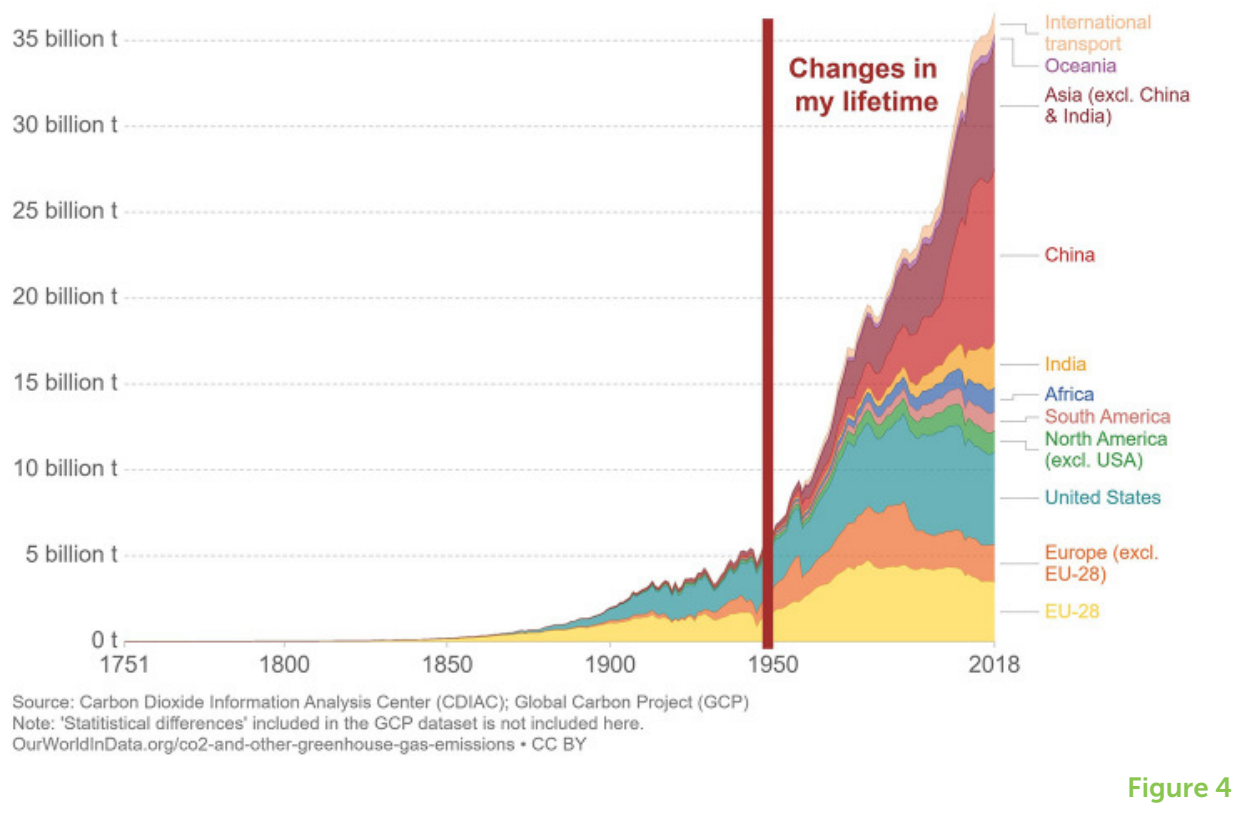

us. In recent centuries, these innovations have increased at warp speed until today, quite suddenly, we have the power to transform the entire planet. Collective learning, our ability to share and accumulate new information, has turned us into the most powerful species on earth.

Sadly, most people alive today still do not understand the scale and importance of what is happening. That is dangerous. If we do not understand what we are doing, we will make bad decisions that will affect the futures of your children and their children and of millions of other species. So, it is vital that we humans learn, very quickly, how to manage a planet. The first step is to see what is happening. Education is vital, but to see the scale of these changes, you need a very wide-angle lens. Courses, such as big history can help us see the challenges more clearly. Education can also show us that we have immense knowledge and fantastic resources. We have the tools needed to build a better world. We know how to reduce our impacts on the land, the climate, the oceans, and other species so that we are spared a completely chaotic future.

But one more thing is needed. We have become powerful by sharing information. Now we need to collaborate across the world. The first step will be to stop burning fossil fuels and look for other sources of energy. The good news is that we already have many of the technologies we need. Making the necessary changes will be difficult because they will harm some people. So, we will need not just new technologies, but also a lot of skillful negotiators and leaders. Changes will also create new opportunities and exciting new ways of doing things. Can we humans work together carefully enough and 
thoughtfully enough to open the doors to a more sustainable future for later generations, for your children and their children? Can we learn to become responsible and ethical planet managers? The future is in our hands.

\section{REFERENCES}

1. Allison, G., and Zelikow, P. 1999. Essence of Decision: Explaining the Cuban Missile Crisis, 2nd Edn. New York, NY: Longman.

2. Rosling, H., and Rosling, O. 2018. Factfulness: Ten Reasons We're Wrong About The World-And Why Things Are Better Than You Think. London:Sceptre.

3. Roser, M. Our World in Data. Available online at: https://ourworldindata.org/ (accessed January 22, 2021).

4. Big History School (A Free Online Course in Big History). Available online at: http://www.bighistoryschool.org/ (accessed January 22, 2021).

5. The Big History Project (The First Free Online Course in Big History). Available online at: https://www.bighistoryproject.com/home (accessed January 22, 2021).

6. The International Big History Association. Available online at: https://bighistory. org/ (accessed January 22, 2021).

SUBMITTED: 02 March 2020; ACCEPTED: 12 January 2021;

PUBLISHED ONLINE: 11 February 2021.

EDITED BY: Mark A. Brandon, The Open University, United Kingdom

CITATION: Christian D (2021) Learning How to Manage a Planet. Front. Young Minds 9:539894. doi: 10.3389/frym.2021.539894

CONFLICT OF INTEREST: The author declares that the research was conducted in the absence of any commercial or financial relationships that could be construed as a potential conflict of interest.

COPYRIGHT @ 2021 Christian. This is an open-access article distributed under the terms of the Creative Commons Attribution License (CC BY). The use, distribution or reproduction in other forums is permitted, provided the original author(s) and the copyright owner(s) are credited and that the original publication in this journal is cited, in accordance with accepted academic practice. No use, distribution or reproduction is permitted which does not comply with these terms.

\section{YOUNG REVIEWERS}

\section{GABRIEL, AGE: 16}

My name is Gabriel, and I live in London. Some things I enjoy include football and sleeping. I also like music, and play the violin. Things I enjoy in school include maths and sciences. 


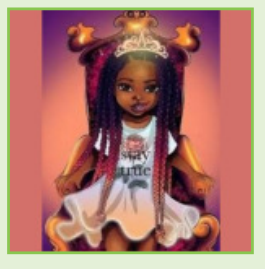

PRICE, AGE: 12

Price loves making up stories and has also written a book (Ms. Wasteson and the waste empire). She enjoys gymnastics, athletics, volleyball, and basketball. She is brave and bouncy. Price also enjoys quality time with family and is very creative. At her school, she is part of a "green team" that works to protect the environment. She likes debating and has a passion to study and become an activist against social injustices.
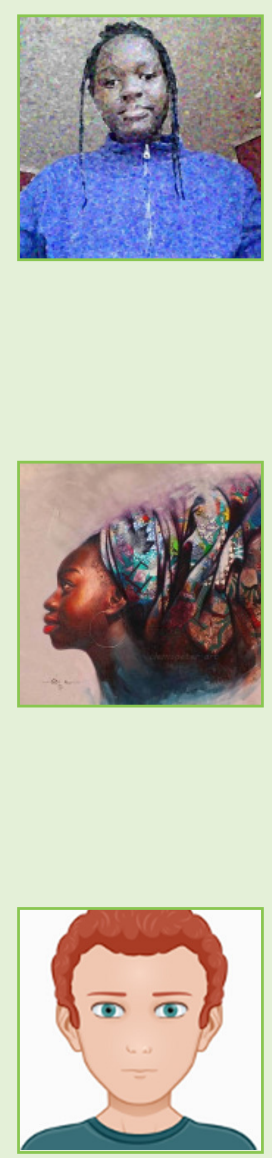

\section{PRINCESS, AGE: 14}

Princess has many ideas and goals and is passionate about helping others to be better. She is a deep thinker while solving problems. Princess is funny, sporty, jumpy and a kind person, who loves exploring to find solutions. She is creative, narrative and likes writing. Princess wrote a book titled "Sarah and the waste center." She loves learning new things. She is into volleyball, music, band, art, and digital photography. Her purpose is to learn more about science, and to improve her writing and editing skills.

\section{PROVIDENCE, AGE: 8}

Providence is the youngest amongst her three sisters. She is playful and bouncy. Providence is curious, talkative, and likes asking many funny questions, that leaves others laughing. She loves making new friends and traveling. Providence loves science experiments. During this process, she may destroy, repair, or recycle some household items. As part of this adventure, Providence repaired a spoilt speaker. But after weeks of action, she modeled the speaker wires into skipping ropes. She is passionate over music and sports.

\section{THEODORE, AGE: 13}

Subjects I enjoy are computing and maths. I like to eat chocolate and play football. Music is also a hobby of mine, which I enjoy spending time on.

\section{AUTHOR}

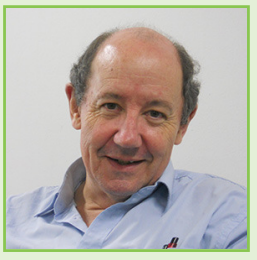

\section{DAVID CHRISTIAN}

David Christian recently retired as Professor of History at Macquarie University in Sydney, Australia. He has also taught in the USA and in Korea. For many years, he taught and researched in Russian and Soviet history, but in the 1990s he started teaching courses in the new field of "big history." These survey the history of the entire Universe. They can help us see how human history fits into the history of planet earth and the Universe as a whole. His latest book on big history is Origin Story, 2018. *david.christian@mq.edu.au 